\title{
$R 127 W-H N F-4 \alpha$ is a loss of function mutation but not a rare polymorphism and causes Type II diabetes in a Japanese family with MODY1
}

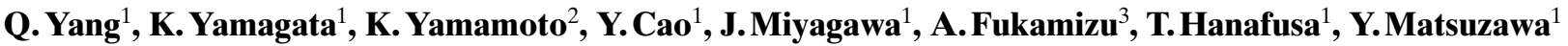 \\ ${ }^{1}$ The Department of Internal Medicine and Molecular Science, Graduate School of Medicine, Osaka University, Japan \\ ${ }^{2}$ The Department of General Medicine, Osaka University Hospital, Osaka, Japan \\ ${ }^{3}$ Centre for Tsukuba Advanced Research Alliance, Institute of Applied Biochemistry, University of Tsukuba, Ibaraki, Japan
}

\begin{abstract}
Aims/hypothesis. Mutations in the hepatocyte nuclear factor $(H N F)-4 \alpha$ gene cause the type 1 form of maturity-onset diabetes of the young (MODY1). The R127W mutation is a missense mutation located in the T-box region of HNF-4 $\alpha$ that was first identified in a Japanese family with MODY. We have examined the functional properties of this mutation in order to clarify the molecular basis of MODY1.

Methods. The intracellular localisation, DNA binding ability, transactivation activity and functional syner-
\end{abstract}

gism with the coactivator CREB-binding protein (CBP) of R127W-HNF-4 $\alpha$ were investigated.

Results. The nuclear import and functional synergy with CBP of R127W-HNF-4 $\alpha$ were normal. The DNA binding ability of the mutant was decreased as was its transcriptional activation of the $H N F-1 \alpha$ and L-type pyruvate kinase $(P K L)$ genes.

Conclusion/interpretation. The R127W mutation seems to be a loss-of-function mutation. [Diabetologia (2000) 43: 520-524]

Keywords MODY, HNF-4 $\alpha$, HNF- $1 \alpha$, L-type pyruvate kinase, insulin.
Maturity-onset diabetes of the young (MODY) is a monogenic form of diabetes mellitus characterised by autosomal dominant inheritance and early onset. Mutations in the hepatocyte nuclear factor $(H N F)$ $4 A$ gene cause MODY1 [1]. Hepatocyte nuclear factor- $4 \alpha$ is a transcription factor and a member of the steroid hormone receptor superfamily. It consists of several functional domains: an N-terminal transactivation domain (AF-1), a DNA binding domain followed by a T-box and an A-box and a functionally

Received: Received: 13 September 1999 and in revised form: 17 January 2000

Corresponding author: K. Yamagata, Department of Internal Medicine and Molecular Science, Graduate School of Medicine, B5, Osaka University, 2-2 Yamada-oka, Suita, Osaka 565-0871, Japan

Abbreviations: MODY, maturity-onset diabetes of the young; CBP, cAMP-responsive element binding protein; PKL, L-type pyruvate kinase; WT, wild-type; TK, thymidine kinase; EMSA, electrophoretic mobility shift assay; HNF, hepatocyte nuclear factor; PI, propidium iodide. complex C-terminal region that forms a ligand binding domain, a dimerisation interface and a transactivation domain (AF-2) [2]. It plays an important part in the regulation of genes involved in a variety of metabolic pathways. The expression of the $H N F-1 \alpha /$ $M O \triangle \Psi 3$ gene is also regulated by HNF- $4 \alpha$.

The R127W mutation is a missense mutation identified in a Japanese family [3]. This mutation changes a conserved arginine located in the T-box (amino acids 117-128), a region which is suggested to be important for dimerisation and DNA binding [2]. Hepatocyte nuclear factor- $4 \alpha$ has been shown to be coactivated by CREB (cAMP-responsive element binding protein) binding protein (CBP) [4]. The region including the arginine residue at 127 has been reported to be critical for the interaction with CBP [4]. Thus, we hypothesised that the $\mathrm{R} 127 \mathrm{~W}$ mutation impairs the functional activity of HNF-4. Recently the transactivation activity of R127W-HNF-4 $\alpha$ has, however been reported to be normal [5]. Here we show that the transcriptional activation of the $H N F-1 \alpha$ and Ltype pyruvate kinase $(P K L)$ promoters is impaired 
by R127W-HNF-4 $\alpha$. The decreased expression of $H N F-1 \alpha$ and $P K L$ genes could contribute to the beta-cell dysfunction that characterises HNF- $4 \alpha$ diabetes.

\section{Methods}

Plasmid constructs. We generated R127W and Q268X-HNF$4 \alpha$ cDNAs using the Chameleon Double-Stranded Mutagenesis Kit (Stratagene, La Jolla, Calif., USA) and subcloned them into pcDNA3.1 (Invitrogen, Carlsbad, Calif., USA). The nucleotide sequence encoding the FLAG epitope (DYKDDDDK) was introduced in the frame at the C-termini of the wild-type (WT) and R127W sequences. The CD1b-HNF$4 \alpha$ mutant is a C-terminal truncated mutant retaining the DNA binding ability [6]. It was generated as described previously [6]. Human HNF-1 $\alpha$ gene promoter (nucleotides -129 to 196) was subcloned into pGL3-basic vector (Promega, Madison, Wis., USA). The promoter region between positions -206 and -7 of the rat PKL gene including the HNF-4 $\alpha$ binding site was amplified by PCR and subcloned into pGL3-basic vector. The sequence of each construct was verified. We inserted eight copies of the HNF- $4 \alpha$ binding site of the mouse transthyretin promoter upstream of the HSV-TK promoter/luciferase fusion gene (pHNF4-tk-Luc). The CBP expression vector, $\mathrm{pRc} / \mathrm{RSV}$ CBP, has been described previously [4].

Cell culture and transient transfection assays. We maintained HeLa and MIN6 cells in D-MEM supplemented with $10 \%$ and $15 \%$ fetal bovine serum, respectively. We used MIN6 cells in experiments between passages 7 to 12 . When reaching $80 \%$ confluence, HeLa and MIN6 cells were detached and plated in 6 -well plates at a density of $1.5 \times 10^{5}$ (HeLa) or $3 \times 10^{5}$ (MIN6) cells per well. Cells were transfected for $3 \mathrm{~h}$ in serumfree OPTI-MEMI (Life Technologies, Rockville, Md., USA) with the indicated amounts of the expression vectors (Fig. 2 legend) and $0.5 \mu \mathrm{g}$ of the reporter genes together with $10 \mathrm{ng}$ of pRL-SV40, the internal control plasmid (Promega), using the LipofectAMINE PLUS Reagent (Life Technologies) according to the manufacturer's protocol. After another 48-h incubation, luciferase activity was measured.

Immunolocalisation of $\mathrm{HNF}-4 \alpha$ in transfected cells. The HeLa cells $\left(1 \times 10^{5}\right)$ grown on Lab-Tek chamber slides (Nalge Nunc, Naperville, Ill., USA) were transfected with $0.5 \mu \mathrm{g}$ of FLAGepitope-tagged WT and R127W-HNF-4 $\alpha$ constructs. After $48 \mathrm{~h}$, cells were fixed with $4 \%$ paraformaldehyde for $10 \mathrm{~min}$ at $4{ }^{\circ} \mathrm{C}$ and blocked with Block Ace (Yukijirushi, Sapporo, Japan) for $40 \mathrm{~min}$ at room temperature. Cells were incubated with mouse anti-FLAG monoclonal antibody (Sigma, St. Louis, Mo., USA) for $12 \mathrm{~h}$ at $4{ }^{\circ} \mathrm{C}$, followed by incubation with biotinylated horse anti-mouse IgG (Vector, Burlingame, Calif., USA) and fluorescein avidin D (Vector). Nuclei were made visible with propidium iodide $(\mathrm{PI})$.

Electrophoretic mobility shift assay (EMSA) and western blot analysis. We used in vitro translated proteins or nuclear cell extract. Wild-type and mutant $\mathrm{HNF}-4 \alpha$ proteins were synthesised using $1 \mu \mathrm{g}$ of pcDNA3.1 construct and TNT T7 Transcription/Translation System (Promega). We transfected HeLa cells $\left(1 \times 10^{6}\right)$ with $8 \mu \mathrm{g}$ of WT or mutant HNF-4 $\alpha$ and nuclear extracts were prepared as described [7]. We used $2 \mu \mathrm{l}$ of the in vitro translated proteins or $3 \mu \mathrm{g}$ of nuclear proteins for EMSA. Proteins were incubated with ${ }^{32} \mathrm{P}$-labelled oligonu- cleotide containing the HNF-4 $\alpha$ binding site of the human $H N F-1 A$ promoter (5'-GGCTGAAGTCCAAAGTTCAGTCCCTTCGC-3') in a $20 \mu \mathrm{l}$ reaction mixture containing $20 \mathrm{mmol} / \mathrm{l}$ HEPES (pH 7.9), $75 \mathrm{mmol} / \mathrm{l} \mathrm{KCl,} \mathrm{3 \%} \mathrm{Ficoll,}$ $1 \mathrm{mmol} / 1 \mathrm{MgCl}_{2}, 0.1 \mathrm{mmol} / \mathrm{l}$ EDTA, $1 \mathrm{mmol} / \mathrm{l}$ dithiothreitol (DTT), $2 \mu \mathrm{g}$ poly (dI-dC) at $25^{\circ} \mathrm{C}$ for $30 \mathrm{~min}$. The DNA-protein complexes were analysed on $5 \%$ polyacrylamide gels using $0.5 \times$ TRIS-borate/EDTA before (TBE) buffer. The polyclonal antibody $(\alpha 445)$ [2] was obtained from Dr F. M. Sladek (University of California). The images were quantified using ScanningImager (Molecular Dynamics, Sunnyvale, Calif., USA). Western blot analysis was done using anti-HNF-4 $\alpha$ antibody (Santa Cruz Biotechnology, Santa Cruz, Calif., USA) [7].

\section{Results}

Subcellular localisation of wild-type and mutant $H N F-4 \alpha$. We transfected HeLa cells with FLAG tagged WT-HNF-4 $\alpha$ and R127W-HNF-4 $\alpha$ constructs (Fig. 1a-d). Out of 133 cells $18(13.5 \%)$ and out of 143 cells $17(11.9 \%)$ were positive for staining, respectively. Immunostaining suggested that both WTHNF- $4 \alpha$ and R127W-HNF-4 $\alpha$ were localised in the nucleus. The nuclear localisation of both proteins was confirmed by the nuclear staining with PI (Fig. 1 c, d), indicating that this mutation does not affect the intracellular localisation.

DNA binding study. We carried out EMSA using in vitro translated HNF-4 $\alpha$. The expressions of WT, R127W and CD1b-HNF-4 $\alpha$ translated in vitro were similar (Fig. 1e). The WT-HNF-4 $\alpha$ construct bound to the oligonucleotide and the binding was blocked by the addition of 50-fold excess of unlabelled probes (Fig. 1f, lanes 1 and 2). The DNA-protein complex was supershifted by the addition of the polyclonal anti-HNF- $4 \alpha$ antiserum, but normal serum did not affect the complex (lanes 3 and 4). The binding of R127W-HNF-4 $\alpha$ was decreased by $47.0 \%$ compared with that of WT-HNF-4 $\alpha$ (lanes 1 and 5).

Equal amounts of WT and CD1b or R127W and CD1 b proteins were mixed and assayed for DNA binding. An additional protein/DNA complex was observed with an intermediate mobility (lanes 7 and 8 ). These results suggest that R127W-HNF-4 $\alpha$ forms a homodimer and heterodimer.

We also carried out EMSA using nuclear extracts from HNF- $4 \alpha$ transfected HeLa cells. We confirmed that the expression level of WT-HNF- $4 \alpha$ and R127WHNF-4 $\alpha$ was the same by western blot analysis (Fig.1g). We found WT-HNF-4 $\alpha$ specifically bound to the oligonucleotide as described above (Fig. $1 \mathrm{~h}$, lanes 1-4) but Q268X-HNF-4 $\alpha$ failed to bind to the oligonucleotide (Fig. $1 \mathrm{~h}$, lane 6) as noted previously [8]. The binding of R127W-HNF-4 $\alpha$ was decreased by $61.7 \%$ compared with that of WT-HNF-4 $\alpha$ (lanes 1 and 5). These data suggest that the R127W mutation affects the DNA binding ability of HNF- $4 \alpha$. 

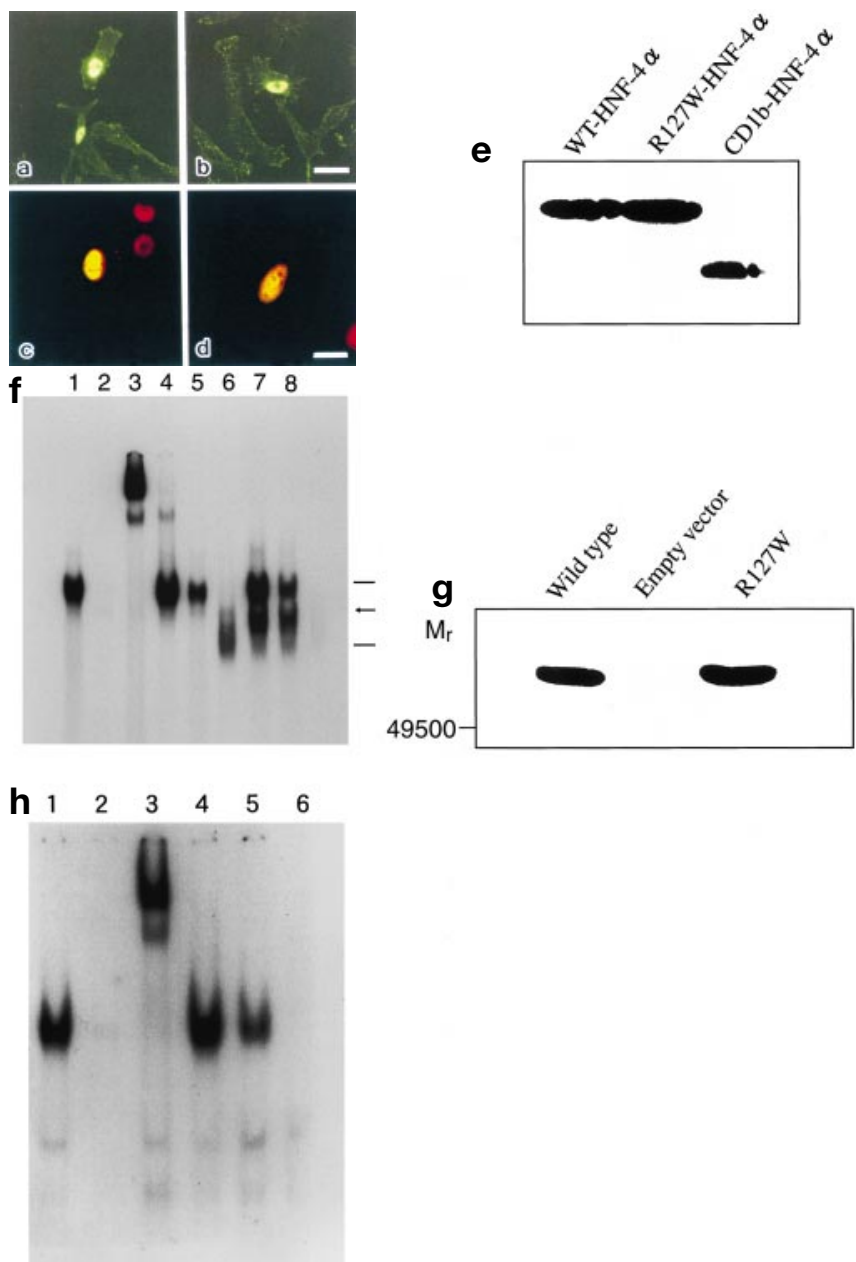

Fig. 1. a-d Subcellular localisation of WT and R127W HNF-4 $\alpha$ in HeLa cells. HeLa cells were transfected with $0.5 \mu \mathrm{g}$ of FLAG-epitope tagged WT and mutant HNF-4 $\alpha$ constructs. Expression of HNF-4 $\alpha-F L A G$ protein (green fluorescence) (a,b). Double exposured with PI staining (red colour) showed yellow fluorescence in the nuclei $(\mathbf{c}, \mathbf{d})$. (a, c) WT-HNF-4 $\alpha$, (b, d) R127W-HNF-4 $\alpha$. Bar $=30 \mu \mathrm{m}(\mathbf{a}, \mathbf{b})$. Bar $=15 \mu \mathrm{m}(\mathbf{c}, \mathbf{d})$. e Expression of in vitro translated WT, R127W and CD1b$\mathrm{HNF}-4 \alpha$ proteins. HNF-4 $\alpha$ proteins were in vitro translated and separated on $10 \%$ SDS-polyacrylamide gel. f EMSA with in vitro translated proteins. Proteins were incubated with ${ }^{32} \mathrm{P}$ labelled oligonucleotide containing the $\mathrm{HNF}-4 \alpha$ binding site of the human HNF-1 $\alpha$ promoter (5'-GGCTGAAGTCCAAAGTTCAGTCCCTTCGC-3') in a $20 \mu \mathrm{l}$ reaction mixture containing $20 \mathrm{mmol} / \mathrm{l} \mathrm{HEPES} \mathrm{(pH} \mathrm{7.9),} 75 \mathrm{mmol} / \mathrm{l} \mathrm{KCl}$, $3 \%$ Ficoll, $1 \mathrm{mmol} / 1 \mathrm{MgCl}_{2}, 0.1 \mathrm{mmol} / \mathrm{l} \mathrm{EDTA}, 1 \mathrm{mmol} / \mathrm{l} \mathrm{DTT}$, $2 \mu \mathrm{g}$ poly (dI-dC) at $25^{\circ} \mathrm{C}$ for $30 \mathrm{~min}$. The DNA-protein complexes were analysed on $5 \%$ polyacrylamide gels using $0.5 \times$ TBE buffer. Lane 1: WT-HNF- $4 \alpha$, lane 2 : WT-HNF-4 $\alpha$ and competitor, lane 3: WT-HNF-4 $\alpha$ and anti-HNF-4 $\alpha$ antiserum, lane 4: WT-HNF-4 $\alpha$ and normal control serum, lane 5: R127W-HNF-4 $\alpha$, lane 6: CD1b-HNF-4 $\alpha$, lane 7: CD1b and WT-HNF-4 $\alpha$, lane 8: CD1 b and R127W-HNF-4 $\alpha$. The arrow indicates the position of the heterodimer between CD1 b and WT/R127W. g Western blot analysis of WT and R127W-HNF$4 \alpha$. Expression of WT and R127W-HNF-4 $\alpha$ in HeLa cells. h EMSA with nuclear proteins extracted from HNF- $4 \alpha$ transfected HeLa cells. Lane 1: WT-HNF-4 $\alpha$, lane 2: WT-HNF-4 $\alpha$ and competitor, lane 3: WT-HNF-4 $\alpha$ and anti-HNF- $4 \alpha$ antiserum, lane 4: WT-HNF-4 $\alpha$ and normal control serum, lane 5: R127W-HNF-4 $\alpha$, lane 6: Q268X-HNF-4 $\alpha$
Transactivation study. The transactivation ability of WT and mutant HNF- $4 \alpha$ was studied in HeLa cells that lack endogenous HNF-4 $\alpha$ activity. We fond WTHNF- $4 \alpha$ stimulated the transcription of the $H N F-1 \alpha$ and $P K L$ promoter-luciferase reporter constructs and generated a statistically significant increase in the reporter gene activity whereas Q268X-HNF-4 $\alpha$ did not (Fig. $2 \mathrm{a}, \mathrm{b})$. The transactivation activity of R127W-HNF-4 $\alpha$ was $70.3 \%(p=0.0072)($ HNF-1 $\alpha)$ and $73.5 \%(p=0.0045)(\mathrm{PKL})$ of that of WT-HNF$4 \alpha$. A reporter construct with a heterologous $T K$ promoter and HNF-4 $\alpha$ binding sequence as an enhancer (pHNF4-tk-Luc) was also used to confirm the impaired transactivation activity of R127W-HNF-4 $\alpha$. The transactivation activity of R127W-HNF-4 $\alpha$ was decreased by $66.2 \%(p=0.001)$ compared with WTHNF-4 $\alpha$ (Fig. $2 c$ ) suggesting that R127W-HNF-4 $\alpha$ represents a loss-of-function mutation.

The transactivation activity of R $127 \mathrm{~W}-\mathrm{HNF}-4 \alpha$ was further investigated using MIN6 cells, an insulin secreting cell line that has endogenous HNF- $4 \alpha$ activity. The transcription of $H N F-1 \alpha, P K L$ and heterologous $T K$ reporters by $\mathrm{R} 127 \mathrm{~W}-\mathrm{HNF}-4 \alpha$ were reduced compared with WT-HNF-4 $\alpha$ : $77.7 \% \quad(p=0.033)$, $77.8 \%(p=0.0075)$ and $48.2 \%(p=0.002)$, respectively (Fig. 2d, e and f).

Because R127W is located in a region of HNF- $4 \alpha$ that interacts with the coactivator CBP, this mutation could impair the functional interaction of HNF- $4 \alpha$ with CBP. Co-transfection of HNF-4 $\alpha$ and CBP constructs stimulated the pHNF4-tk-Luc reporter gene activity by 4.0 -fold compared with the transfection of HNF-4 $\alpha$ alone. The CBP construct also increased the transcriptional activity of R127W-HNF-4 $\alpha$ by 4.7-fold (Fig. $2 \mathrm{~g}$ ), suggesting that there is no impaired synergy between R127W-HNF-4 $\alpha$ and CBP in the system.

\section{Discussion}

We have previously shown that mutations in the $M O D Y 3 / H N F-1 \alpha$ gene result in diverse functional consequences including impairment of DNA binding ability, improper intracellular localisation and reduced transcriptional activity [7]. In this study, we have shown that the nuclear import and functional synergy with CBP of R127W-HNF-4 $\alpha$ are normal and the DNA binding and the transactivation ability of this mutation are reduced. Impairment of the synergistic effect between another missense mutation (E276Q-HNF-4 $\alpha$ ) and COUP-TFII on the transcription of HNF-1 $\alpha$ has been reported [9]. The decreased binding ability of R127W-HNF-4 $\alpha$ suggests the conserved arginine residue is important for the binding. The decreased binding ability of R127WHNF-4 $\alpha$ might account for its reduced transactivation activity. 

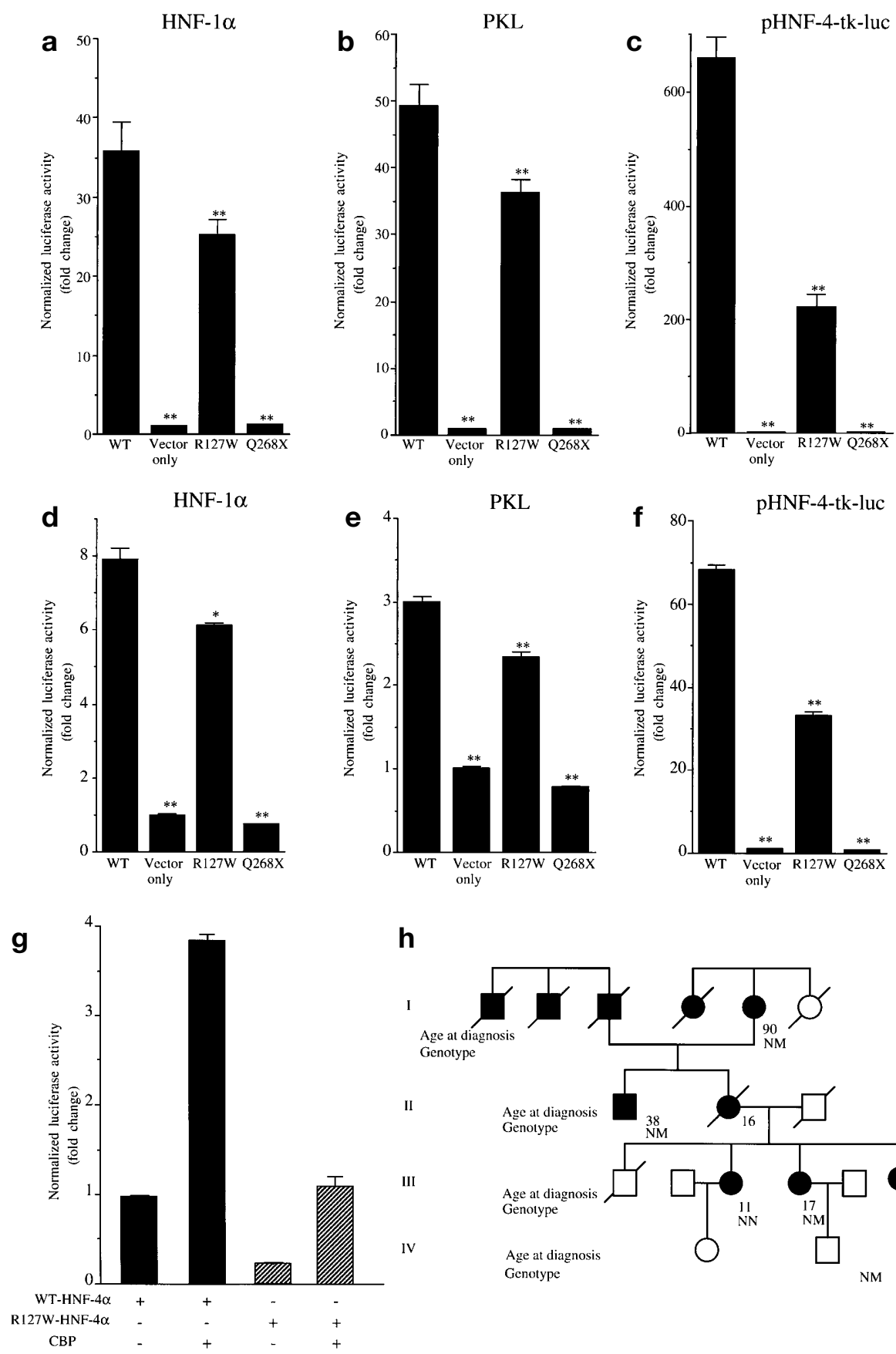

h

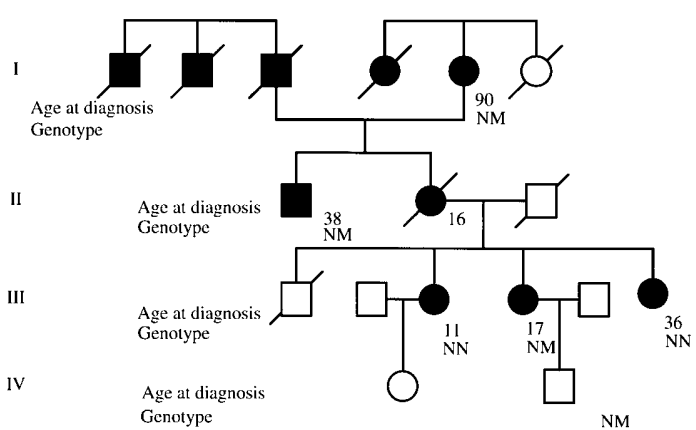

Fig. 2. a-f Transactivation activities of WT and mutant HNF$4 \alpha$ in HeLa cells $(\mathbf{a}, \mathbf{b}, \mathbf{c})$ and MIN6 cells (d, e, f). Cells were transfected with $0.5 \mu \mathrm{g}$ of the WT or mutant HNF-4 $\alpha$ constructs and $0.5 \mu \mathrm{g}$ of the reporter genes together with $10 \mathrm{ng}$ of pRL-SV40. HNF-1 $\alpha$ reporter $(\mathbf{a}, \mathbf{d})$, PKL reporter $(\mathbf{b}, \mathbf{e})$, pHNF4-tk-Luc $(\mathbf{c}, \mathbf{f})$. The results were from three independent experiments; means \pm SEM, ${ }^{*} p<0.05, * * p<0.01$. g Synergistic effect between HNF-4 $\alpha$ and CBP on the pHNF4-tk-Luc reporter. HeLa cells were transfected with $0.1 \mu \mathrm{g}$ of pcDNA3.1-WT- or R127W-HNF-4 $\alpha$ and $1 \mu \mathrm{g}$ of pRc/RSVCBP. The results were from three independent experiments; means \pm SEM, ${ }^{*} p<0.05, * * p<0.01$. h The pedigree of the family with the R127W mutation [3]. Subjects with diabetes are noted by filled symbols and non-diabetic (or not tested) by open symbols. The age at diagnosis and the genotype are noted: N, normal; M, mutant (R127W)
The R127W mutation was present in 3 out of 5 of the diabetic patients we examined (in total 4 because subject II-2 can be assumed to have the R127W mutation) [3] (Fig. 2h). The age at diagnosis of the diabetic patients with the mutation ranged from 17-90 years [3]. Such a variable penetrance of the mutant allele could be a consequence of the relatively mild nature of this mutation. There were two affected members who did not have the mutation (III-3 and III-6). They could have another form of Type II diabetes because diabetes was transmitted from both parents. Such aetiological heterogeneity has been noted previously [10].

It has recently been reported that the transactivation activity of R127W-HNF-4 $\alpha$ is normal and sug- 
gested that this mutation is a rare polymorphism [5]. Our results suggest otherwise. We do not have an adequate explanation to account for the difference. That study used two reporter constructs; pZLHIVA1-4 which contains four HNF4 binding sites of the apolipoprotein A1 upstream of an HIV-LTR basal promoter and pLZ100 which contains apolipoprotein CIII promoter containing one HNF4 binding site. It is known that HNF-4 $\alpha$ activity depends on the promoter context [6]. The difference of the reporter systems might have contributed to the different results.

The transcription of the $H N F-1 \alpha$ and $P K L$ genes by R127W-HNF-4 $\alpha$ were decreased. The HNF-1 $\alpha$ transcription factor regulates the expression of genes involved in the glucose homeostasis (e.g. GLUT2, $P K L$ and insulin) in pancreatic beta-cells [7]. Thus, the mechanism by which R127W-HNF-4 $\alpha$ leads to beta-cell dysfunction could be through HNF-1 $\alpha$ both directly and indirectly. Identification of the target genes of HNF- $4 \alpha$ action in the beta cell should lead to a better understanding of the molecular pathogenesis of MODY1/HNF-4 $\alpha$ diabetes.

Acknowledgements. We thank Dr G. Bell (University of Chicago) for his continued encouragement and support. We also thank Dr J. Miyazaki (Osaka University) for providing MIN6 cells and Dr F. M. Sladek (University of California) for providing HNF- $4 \alpha$ antibody. This work was supported by grants from the Japanese Ministry of Science, Education and Culture, Japan Insulin Study Group, Ryoichi Naito Foundation for Medical Research, Senri Life Science Foundation, Research for the Future Programme of The Japan Society for the Promotion of Science (97L00 801) and Japanese Ministry of Health and Welfare (Health Science Research Grants, Research on Human Genome and Gene Therapy). K. Yamagata is a research fellow of the Japan Society for the Promotion of Science.

\section{References}

1. Yamagata K, Furuta H, Oda N et al. (1996) Mutations in the hepatocyte nuclear factor- $4 \alpha$ gene in maturity-onset diabetes of the young (MODY1). Nature 384: 458-460

2. Jiang G, Sladek FM (1997) The DNA binding domain of hepatocyte nuclear factor 4 mediates cooperative, specific binding to DNA and heterodimerization with the retinoid $\mathrm{X}$ receptor $\alpha$. J Biol Chem 272: 1218-1225

3. Furuta H, Iwasaki N, Oda N et al. (1997) Organization and partial sequence of the hepatocyte nuclear factor- $4 \alpha /$ MODY1 gene and identification of a missense mutation, $\mathrm{R} 127 \mathrm{~W}$, in a Japanese family with MODY. Diabetes 46: 1652-1657

4. Yoshida E, Aratani S, Itou H et al. (1997) Functional association between CBP and HNF4 in trans-activation. Biochem Biophys Res Commun 241: 664-669

5. Navas MA, Munoz-Elias EJ, Kim J et al. (1999) Functional characterization of the MODY1 gene mutations HNF4 (R127W), HNF4 (V255M), and HNF4 (E276Q). Diabetes 48: $1459-1465$

6. Hadzopoulou-Cladaras M, Kistanova E, Evagelopoulou C et al. (1997) Functional domains of the nuclear receptor hepatocyte nuclear factor 4. J Biol Chem 272: 539-550

7. Yamagata K, Yang Q, Yamamoto K et al. (1998) Mutation $\mathrm{P} 291 \mathrm{fsins} \mathrm{C}$ in the transcription factor hepatocyte nuclear factor- $1 \alpha$ is dominant negative. Diabetes 47: 1231-1235

8. Stoffel M, Duncan S (1997) The maturity-onset diabetes of the young (MODY1) transcription factor HNF4 $\alpha$ regulates expression of genes required for glucose transport and metabolism. Proc Natl Acad Sci USA 94: 13209-13214

9. Suaud L, Hemimou Y, Formstecher P et al. (1999) Functional study of the E276Q mutant hepatocyte nuclear factor- $4 \alpha$ found in type 1 maturity-onset diabetes of the young: Impaired synergy with chicken ovalbumin upstream promoter transcription factor II on the hepatocyte nuclear factor-1 promoter. Diabetes 48: 1162-1167

10. Bell GI, Xiang KS, Newman MV et al. (1991) Gene for non-insulin-dependent diabetes mellitus (maturity-onset diabetes of the young subtype) is linked to DNA polymorphism on human chromosome 20q. Proc Natl Acad Sci USA 88: 1484-1488 